\title{
Resolution on the Restoration of the United Nations Depository Library System
}

Editor's note: A digital version of this resolution can be found at www.ala.org/offices/ resolution-restoration-united-nations -depository-library-system.

Whereas ALA Policy 6.1.1 International Relations Policy Objectives is "To encourage the exchange, dissemination, and access to information and the unrestricted flow of library materials in all formats throughout the world (ALA Key Action Area: Equitable Access to Information and Library Services)";

Whereas United Nations Policy, as found in the Principles Governing Depository Libraries, states that "all depository libraries shall receive automatically, according to their needs, all publications offered for sale and public information material distributed free, if available in the official language of their choice" (UN Doc: ST/ AI/189/Add.11/Rev.2);

Whereas the United Nations (UN) dedicates its programs, services and mission to the promotion of fundamental human rights and freedoms, which must include the free flow of public and government information internationally;

Whereas the UN, over the last 70 years, is one of the primary producers of internationally shared information, documents, publications and other critical sources of knowledge that support fundamental rights and freedoms, and that these critical public information sources remain part of our international historic record that benefit researchers and users around the world;
Whereas the UN's Sustainable Development Goals 16.6, 16.7, 16.8 and 16.10 rely upon a clearly transparent form of information creation and distribution that allows for the ready access to these sources of public knowledge as key components of national and international governance structures and sustainable development;

Whereas since its establishment in 1946, the UN manages a low-cost and publicly accessible depository library program that enables partner libraries and their institutions to provide free and ready public access to vital UN resources, expert knowledge, and that supports the human right to the free flow of international government information;

Whereas 365 UN depository libraries located in 136 countries represent a high level of relatively low-cost accessible collections to a large number of people, and provides the sole presence and critical knowledge and information about UN Secretariat activities, programs and services in 83 countries;

Whereas the depository library program remains one of best examples of how the shared expert knowledge of librarians can help local communities navigate a complex set of government datasets, knowledge and information tools;

Whereas United Nations Depository librarians have been solid partners with the Dag Hammarskjöld Library (DHL) since 1946;

Whereas the estimated annual cost of the new commercial model for the United
Nations iLibrary online platform will be cost prohibitive for many UN depository libraries, and result in diminished access and participation of the depository libraries to collect and distribute $\mathrm{UN}$ information in the future;

Whereas shifting critical UN information sources to a primarily online platform would disadvantage communities around the globe that are without reliable access to the Internet, especially in developing countries or those under distress from war, ecological disasters, or economic disadvantages; and

Whereas the UN Department of Public Information (DPI) needs to more carefully consider the recommendations of the UN depository library community, solicited via A New Strategic Direction for UN Depository Libraries Consultation Paper, issued by the DHL in April 2014; now, therefore, be it

Resolved, that the American Library Association (ALA), on behalf of its members, urges the UN to take steps to ensure the long-term equitable access to its information products by:

1. reinstating the print depository library program for countries in areas of the world where the cost of Internet access is too high and not widely developed, so as to ensure transparent and ready access to UN information worldwide, and to continue to operate this program parallel to its online platforms, the United Nations iLibrary and the UN Digital Repository;

2. providing the United Nations Depository Library Program with free access 
to the iLibrary in order to assure equitable access to all member countries of the United Nations, in the spirit other languages of the Principles Governing Depository Libraries;

3. abiding by the recommendations made by depository libraries concerning the Consultation Paper, which were submitted to the UN Department of Public Information in June 2014 and published in the Executive Summary on the Analysis of Responses to the Consultation Paper on the Re-engineering of the UN Depository Libraries Programmes that Depository Libraries "receive a comprehensive and integrated service from DHL including distribution of relevant paid/unpaid publications and documents through the Digital Repository," including implementing and adhering to a digital preservation policy and considering delaying the UN iLibrary in order to consult with corresponding stakeholders (i.e. Dag Hammersköld Library and United Nations Depository Libraries (UNDLs);

4. encouraging full cooperation and communication among the United Nations Depository Library Program, UN Publications, and the UN Department of Public Information to assure the broadest possible access to UN documents and publications; and

5. respecting existing UN policy, which states, "The United Nations Publications Board, on the advice of the Head
Librarian of the Dag Hammarskjöld Library and taking into account the views of the Government concerned, designates depository libraries" (UN Doc: ST/AI/I89/Add.11/Rev.2), by appointing a working panel to study the issues, comprised of representatives from the Dag Hammarskjöld Library, the Publications Board, and Depository Libraries.

Adopted by the Council of the American Library Association

Monday, June 27, 2016, in Orlando, Florida

Keith Michael Fiels

Executive Director and Secretary of the ALA Council 